\title{
12. SILICOFLAGELLATES AND EBRIDIANS FROM LEG 55
}

\author{
Hsin Yi Ling, Department of Geology, Northern Illinois University, DeKalb, Illinois
}

\section{INTRODUCTION}

Leg 55 of the Deep Sea Drilling Project (DSDP) was proposed to drill a few holes on the Emperor Seamounts of the North Pacific Ocean. The plan had a special appeal to the author because deep-sea sediments recovered from this part of the North Pacific could be the "missing link" bridging the biostratigraphic zonation of silicoflagellates and ebridians previously recognized from high- and low- to middle-latitude areas (Ling, 1973, 1975). At the same time, such zonation in the eastern North Pacific region had been documented (Ling, 1977), and a similar study in the western counterparts was being concluded. Furthermore, biostratigraphic succession of these siliceous microplanktonic remains observed from submarine sequence had already been successfully applied to, and/or compared with, those on the land outcrops of the circum-North Pacific regions (Ling, 1977; Ling and McPherson, 1976). Leg 55 was significant further because no further drilling has been scheduled in this corner of the Pacific by the project until 1981, at the earliest.

With these considerations and the progress in this field as background, the D/V Glomar Challenger left Honolulu, Hawaii on 22 July 1977, and after having drilled 11 holes at four sites (Figure 1, Table 1), ended the cruise at Yokohama, Japan on 6 September 1977.

Methods involving laboratory preparation of these deep-sea sediments, such as the manner of recording the illustrated specimens in the strewn slides by using an England Finder, and reporting their relative abundances (A, abundant; C, common; F, few; R, rare) and states of preservation (G, good; F, fair; $P$, poor) are essentially the same as those of previous reports (Ling, 1973, 1975).

All the slides examined and described in this report will be deposited permanently in the Micropaleontological Collection, Department of Oceanography, University of Washington.

\section{CENOZOIC SILICOFLAGELLATE AND EBRIDIAN BIOSTRATIGRAPHY OF THE WESTERN NORTH PACIFIC}

As it has in almost all the other microplankton groups, our knowledge of temporal and spatial distribution of silicoflagellates and ebridians throughout the Cenozoic has been greatly advanced during the last decade. At the beginning of this decade, many earth scientists held doubts about the biostratigraphic potential for this group of siliceous microfossils. In sharp contrast, today there is a chapter dealing with silicoflagellates and ebridians, either singularly or jointly with other microfossils, in each volume of the Initial Reports.

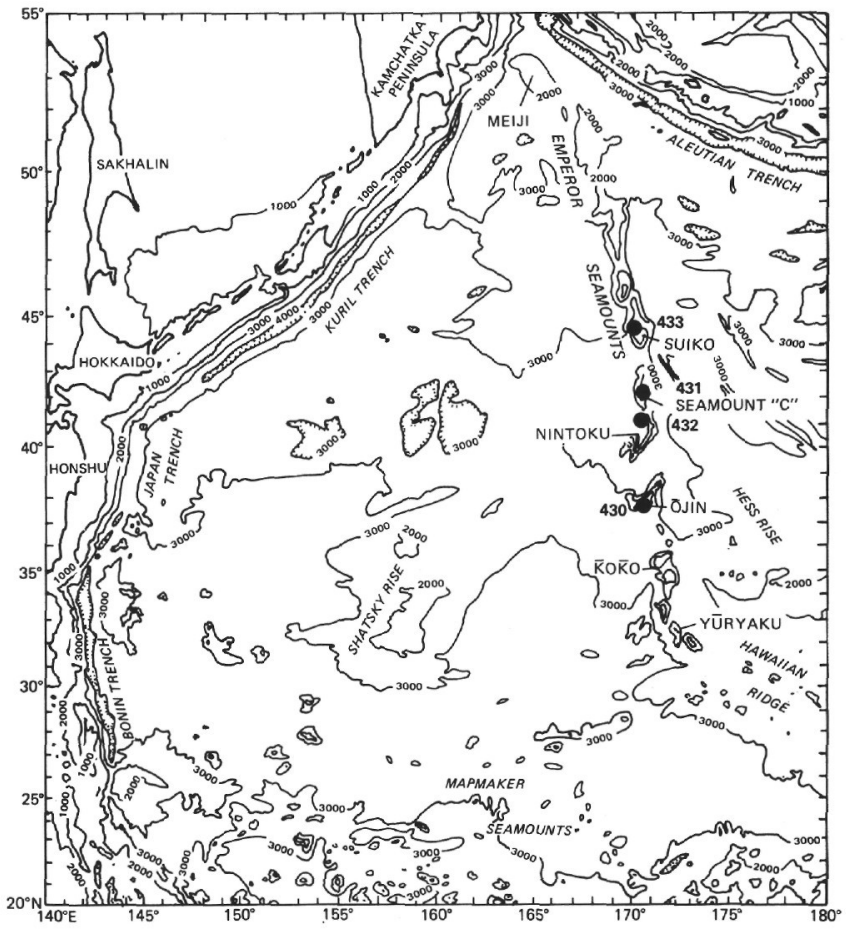

Figure 1. Index map of the northwestern Pacific, showing sites drilled during Leg 55 of the Deep Sea Drilling Project.

In the North Pacific, biostratigraphic zonation of silicoflagellates and ebridians has been proposed, a more comprehensive treatment for the eastern part presented (Ling, 1977), and the westward extension of a similar study almost completed. The combination of these studies provides the working framework (Table 2) for analysis of submarine sediments from each drilled site during the cruise. Analyses of individual sites will be discussed later.

The locations of drilled sites in the western Pacific until Leg 33 are shown in Figure 2. The oldest silicoflagellate-bearing sediments from this part of the Pacific are upper Eocene. These sediments from Holes 165A and 166, are characterized by the occurrence of Corbisema bimucronata together with Corbisema hastata minor (Table 3). This assemblage is probably Dictyocha bimucronata Zone of Martini (1974), which is defined as "the interval from the last occurrence of Dictyocha spinosa (Deflandre) to the first occurrence of Mesocena apiculata (Schulz)," with DSDP Sample 65-1-8, CC of the equatorial Pacific as the reference locality. Martini further listed Dictyocha triacantha Ehrenberg, Pseudorocella barbadiensis Deflandre, and Phyllodictyocha schulzi Deflandre as common species for the zone. This 
TABLE 1

Coordinates of Drilling Sites and Coring Summary of DSDP Leg 55

\begin{tabular}{|c|c|c|c|c|c|c|c|c|c|c|c|}
\hline \multirow[b]{2}{*}{ Hole } & \multirow[b]{2}{*}{$\begin{array}{l}\text { Latitude (N) } \\
\text { Longitude (E) }\end{array}$} & \multirow[b]{2}{*}{$\begin{array}{l}\text { Water Depth } \\
\text { (m) }\end{array}$} & \multirow[b]{2}{*}{$\begin{array}{l}\text { Penetration } \\
\text { (m) }\end{array}$} & \multirow[b]{2}{*}{ Cores } & \multirow[b]{2}{*}{$\begin{array}{c}\text { Total } \\
\text { Cored } \\
\text { (m) }\end{array}$} & \multirow[b]{2}{*}{$\begin{array}{c}\text { Meters } \\
\text { Recovered }\end{array}$} & \multirow[b]{2}{*}{ Recovery (\%) } & \multicolumn{4}{|c|}{ Soft Sediments } \\
\hline & & & & & & & & Cores & $\begin{array}{l}\text { Cored } \\
\text { Length } \\
\text { (m) }\end{array}$ & $\begin{array}{c}\text { Meters } \\
\text { Recovered }\end{array}$ & Recovery (\%) \\
\hline 430 & $\begin{array}{r}37^{\circ} 58.88^{\prime} \\
170^{\circ} 35.45^{\prime}\end{array}$ & 1464.0 & 14.0 & 3 & 14.0 & 7.90 & 56.4 & 3 & 14.0 & 7.90 & 56.4 \\
\hline $430 \mathrm{~A}$ & $\begin{array}{r}37^{\circ} 59.29^{\prime} \\
170^{\circ} 35.86^{\prime}\end{array}$ & 1485.5 & 118.0 & 11 & 85.5 & 16.83 & 19.7 & 4 & 34.0 & 4.00 & 11.8 \\
\hline $430 \mathrm{~B}$ & $\begin{array}{r}37^{\circ} 59.52^{\prime} \\
170^{\circ} 36.12^{\prime}\end{array}$ & 1492.0 & 3.0 & 1 & 3.0 & 0.10 & 3.3 & 1 & 3.0 & 0.10 & 3.3 \\
\hline 431 & $\begin{array}{r}42^{\circ} 25.44^{\prime} \\
170^{\circ} 32.68^{\prime}\end{array}$ & 1714.5 & 9.5 & 2 & 9.5 & 3.33 & 35.1 & 2 & 19.0 & 3.33 & 17.5 \\
\hline $431 \mathrm{~A}$ & $\begin{array}{r}42^{\circ} 25.39^{\prime} \\
170^{\circ} 32.60^{\prime}\end{array}$ & 1713.5 & 17.0 & 2 & 17.0 & 4.35 & 25.6 & 2 & 17.0 & 4.35 & 25.6 \\
\hline 432 & $\begin{array}{r}41^{\circ} 20.03^{\prime} \\
170^{\circ} 22.74^{\prime}\end{array}$ & 1320.0 & 17.5 & 1 & 5.5 & 3.00 & 54.5 & 1 & 5.5 & 3.00 & 54.5 \\
\hline $432 \mathrm{~A}$ & $\begin{array}{r}41^{\circ} 20.03^{\prime} \\
170^{\circ} 22.74^{\prime}\end{array}$ & 1320.0 & 74.0 & 5 & 38.0 & 15.92 & 42.4 & 2 & 19.0 & 3.70 & 19.5 \\
\hline 433 & $\begin{array}{r}44^{\circ} 46.60^{\prime} \\
170^{\circ} 01.26^{\prime}\end{array}$ & 1874.0 & 45.0 & 1 & 5.5 & 5.50 & 100.0 & 1 & 5.5 & 5.50 & 100.0 \\
\hline $433 \mathrm{~A}$ & $\begin{array}{r}44^{\circ} 46.60^{\prime} \\
170^{\circ} 01.26^{\prime}\end{array}$ & 1874.0 & 174.0 & 21 & 174.0 & 88.59 & 50.9 & 19 & 163.5 & 80.46 & 49.2 \\
\hline $433 \mathrm{~B}$ & $\begin{array}{r}44^{\circ} 46.63^{\prime} \\
170^{\circ} 01.23^{\prime}\end{array}$ & 1874.0 & 186.5 & 7 & 58.0 & 10.72 & 18.5 & 7 & 58.0 & 10.72 & 18.5 \\
\hline \multirow[t]{2}{*}{$433 \mathrm{C}$} & $\begin{array}{r}44^{\circ} 46.63^{\prime} \\
170^{\circ} 01.23^{\prime}\end{array}$ & 1874.0 & 550.5 & 50 & 387.5 & 250.15 & 64.6 & 3 & 18.5 & $4.53^{\mathrm{a}}$ & 24.5 \\
\hline & Total & & 1209.0 & 104 & 797.5 & 406.39 & 51.0 & 45 & 357.0 & 127.59 & 35.7 \\
\hline
\end{tabular}

${ }^{a}$ Reef carbonate sands sandwiched between the flows.

TABLE 2

Biostratigraphic Framework for Silicoflagellates in the

\begin{tabular}{|c|c|c|c|c|c|}
\hline \multirow{2}{*}{\multicolumn{2}{|c|}{ Chronostratigraphy }} & \multirow[b]{2}{*}{$\begin{array}{l}\text { High Latitude } \\
\text { (Ling, 1973; } \\
\text { 1977; this paper) }\end{array}$} & \multicolumn{2}{|c|}{ Middle Latitude } & \multirow[b]{2}{*}{$\begin{array}{l}\text { Low Latitude } \\
\text { (Ling, 1977; } \\
\text { this paper) }\end{array}$} \\
\hline & & & $\begin{array}{l}\text { East Nor th Pacific } \\
\text { (Ling, 1977) }\end{array}$ & $\begin{array}{c}\text { Japan Sea } \\
\text { (Ling, 1975) }\end{array}$ & \\
\hline \multirow{3}{*}{ 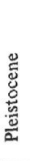 } & \multirow{2}{*}{ Upper } & $\begin{array}{l}\text { Distephanus } \\
\text { octangulatus }\end{array}$ & \multirow[b]{2}{*}{$\begin{array}{l}\text { Distephanus } \\
\text { octangulatus }\end{array}$} & \multirow[b]{2}{*}{$\begin{array}{l}\text { Distephanus } \\
\text { octangulatus }\end{array}$} & \multirow{2}{*}{$\begin{array}{l}\text { Dictyocha } \\
\text { mandraii }\end{array}$} \\
\hline & & $\begin{array}{l}\text { Distephanus } \\
\text { octonarius }\end{array}$ & & & \\
\hline & Lower & $\begin{array}{l}\text { Dictyocha } \\
\text { subarctios }\end{array}$ & $\begin{array}{l}\text { Dictyocha } \\
\text { subarctios }\end{array}$ & $\begin{array}{l}\text { Dictyocha } \\
\text { subarctios }\end{array}$ & $\begin{array}{l}\text { Mesocena } \\
\text { quadrangula }\end{array}$ \\
\hline \multirow{3}{*}{ 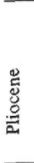 } & Upper & $\begin{array}{l}\text { Ammodochium } \\
\text { rectangtulare }\end{array}$ & $\begin{array}{l}\text { Ammodochium } \\
\text { rectangulare }\end{array}$ & $\begin{array}{l}\text { Ammodochium } \\
\text { rectangulare }\end{array}$ & \multirow{3}{*}{$\begin{array}{l}\text { Dictyocha } \\
\text { brevispina }\end{array}$} \\
\hline & \multirow{2}{*}{ Lower } & $\begin{array}{l}\text { Ebriopsis } \\
\text { antiqua antiqua }\end{array}$ & $\begin{array}{l}\text { Ebriopsis } \\
\text { antiqua antiqua }\end{array}$ & $\begin{array}{l}\text { Ebriopsis } \\
\text { antiqua antiqua }\end{array}$ & \\
\hline & & $\begin{array}{l}\text { Distephanus } \\
\text { jimlingii }\end{array}$ & $\begin{array}{l}\text { Distephanus } \\
\text { jimlingii }\end{array}$ & $\begin{array}{l}\text { Distephanus } \\
\text { iimlingii }\end{array}$ & \\
\hline \multirow{6}{*}{ 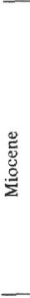 } & \multirow{2}{*}{ Upper } & $\begin{array}{l}\text { Distephanus } \\
\text { quinquangellus }\end{array}$ & & & \multirow{3}{*}{$\begin{array}{l}\text { Dictyocha } \\
\text { aspera aspera }\end{array}$} \\
\hline & & $\begin{array}{l}\text { Mesocena circulus } \\
\text { apiculata }\end{array}$ & $\begin{array}{l}\text { Dictyocha } \\
\text { pseudofibula }\end{array}$ & & \\
\hline & \multirow{3}{*}{ Middle } & $\begin{array}{l}\text { Distephanus } \\
\text { schauinslandii }\end{array}$ & $\begin{array}{l}\text { Distephanus } \\
\text { longispinus }\end{array}$ & & \\
\hline & & $\begin{array}{l}\text { Corbisema } \\
\text { triacantha }\end{array}$ & $\begin{array}{l}\text { Corbisema } \\
\text { triacantha }\end{array}$ & & $\begin{array}{l}\text { Corbisema } \\
\text { triacantha }\end{array}$ \\
\hline & & & $\begin{array}{l}\text { Distephanus } \\
\text { octacanthus }\end{array}$ & & $\begin{array}{l}\text { Distephanus } \\
\text { octacanthus }\end{array}$ \\
\hline & Lower & & & & $\begin{array}{l}\text { Eunaviculopsis } \\
\text { ponticulus }\end{array}$ \\
\hline \multirow{2}{*}{ 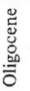 } & \multirow{2}{*}{ Upper } & & & & Rocella gemma \\
\hline & & & & & Naviculopsis lata \\
\hline
\end{tabular}

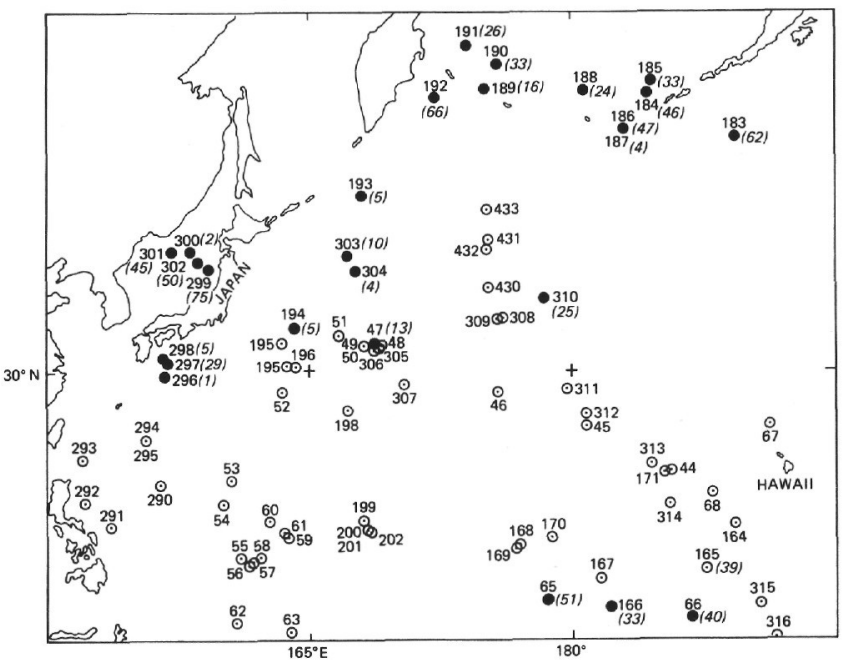

Figure 2. Locations of drilled sites during DSDP Leg 55 in the western North Pacific. Solid circles indicate where cured sediments were examined for silicoflagellates and ebridians; number of samples analyzed from site during investigation shown in parentheses and italicized. 
TABLE 3

Silicoflagellates and Ebridians from Sediments Bearing Corbisema bimucronata in the Western North Pacific, Holes $165 \mathrm{~A}$ and 166

\begin{tabular}{|c|c|c|c|c|c|}
\hline Hole & $\begin{array}{c}\text { Sample } \\
\text { (Interval } \\
\text { in } \mathrm{cm} \text { ) }\end{array}$ & & 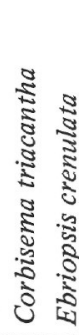 & 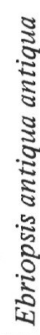 & 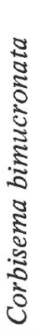 \\
\hline $165 \mathrm{~A}$ & $\begin{array}{l}7-2,120-121 \\
7-4,120-121 \\
7-6,119-120 \\
8-2,119-120 \\
8-4,119-120 \\
8-6,120-121 \\
9-1,50-51 \\
\end{array}$ & $R$ & $\begin{array}{l}- \\
\mathrm{R} \\
\\
+\quad \mathrm{R} \\
\\
-\quad \mathrm{R} \\
\end{array}$ & $\begin{array}{l}\mathrm{R} \\
+ \\
+ \\
-\end{array}$ & $\begin{array}{l}\mathrm{C} \\
\mathrm{R} \\
-\end{array}$ \\
\hline 166 & $\begin{array}{l}10-5,120-121 \\
12-1,30-31 \\
12-4,120-121 \\
12-6,120-121 \\
13-2,120-121 \\
13-4,120-121 \\
13-6,120-121 \\
14-2,120-121\end{array}$ & $\begin{array}{l}\mathrm{R} \\
\mathrm{R} \\
\mathrm{R}\end{array}$ & $\begin{array}{ll}- & - \\
\mathrm{C} & \\
+ & \mathrm{C} \\
& \mathrm{R} \\
& \mathrm{R} \\
& \mathrm{R} \\
+ & \mathrm{R} \\
- & -\end{array}$ & $\begin{array}{l}\mathrm{F} \\
\mathrm{R} \\
\mathrm{R} \\
\mathrm{R} \\
-\end{array}$ & $\begin{array}{l}F \\
R\end{array}$ \\
\hline
\end{tabular}

Note: $\mathrm{R}=$ rare $\mathrm{F}=$ few $\mathrm{C}=$ common, $+=$ present.

zone is correlated with the lower part of the NP 20 (Sphenolithus pseudoradians) Zone. Later, the Dictyocha bimucronata Zone, on the basis of results of the Leg 38 investigation (Norwegian Sea), was amended to include "...from the first occurrence of Dictyocha quadria (Mandra) to the first occurrence of Mesocena apiculatae." The zone included Corbisema apiculata (Lemmermann), Mesocena oamaruensis (Schulz), Naviculopsis ponticula (Perch-Nielsen), and Corbisema flexuosa (Stradner) as the common species (Martini and Müller, 1976). The zone was then correlated with NP 17 (Discoaster saipanensis) and NP 18 (Chiasmolithus oamaruensis) (calcareous nannoplankton) zones. It should be noted here that, besides the occurrences of Corbisema bimucronata and Corbisema triacantha (=Dictyocha triacantha), the western North Pacific assemblage lacks all of the above common species. Furthermore, no such silicoflagellate assemblage was recognized from the eastern Pacific submarine deposits.

The Oligocene through lower Miocene section can be regarded for practical purposes as barren of this group of microfossils.

The combined Neogene biostratigraphic zonation is presented here (see Table 2), and the definition of the zones has been presented in previous articles. The occurrence of each zone, or its coeval section recognized from the examined site, is shown in ascending order in Figures 3 through 12. As in the previous eastern Pacific

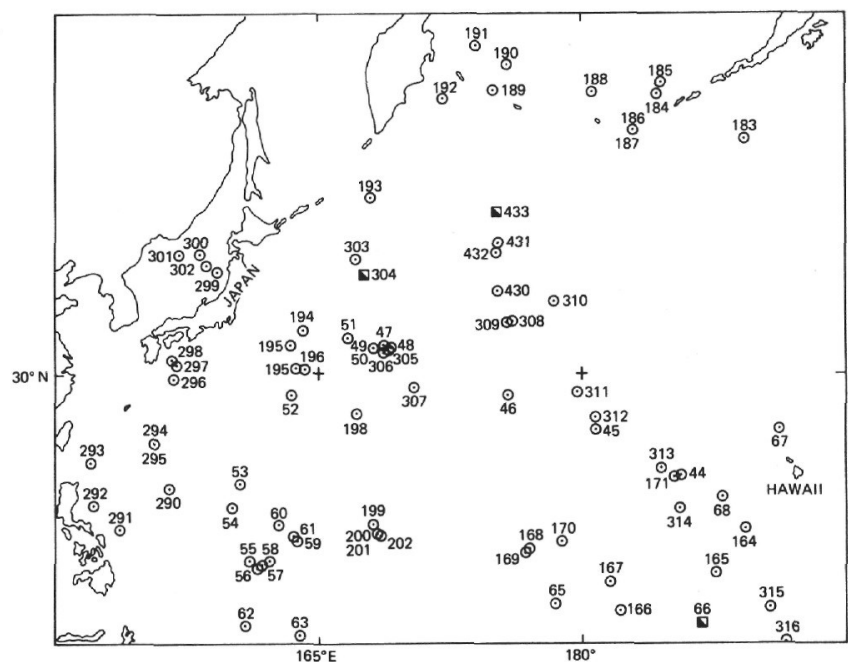

Figure 3. Distribution of sediments of Corbisema triacantha and coeval zone in the western North Pacific. (See Table 2 for key to symbols.)

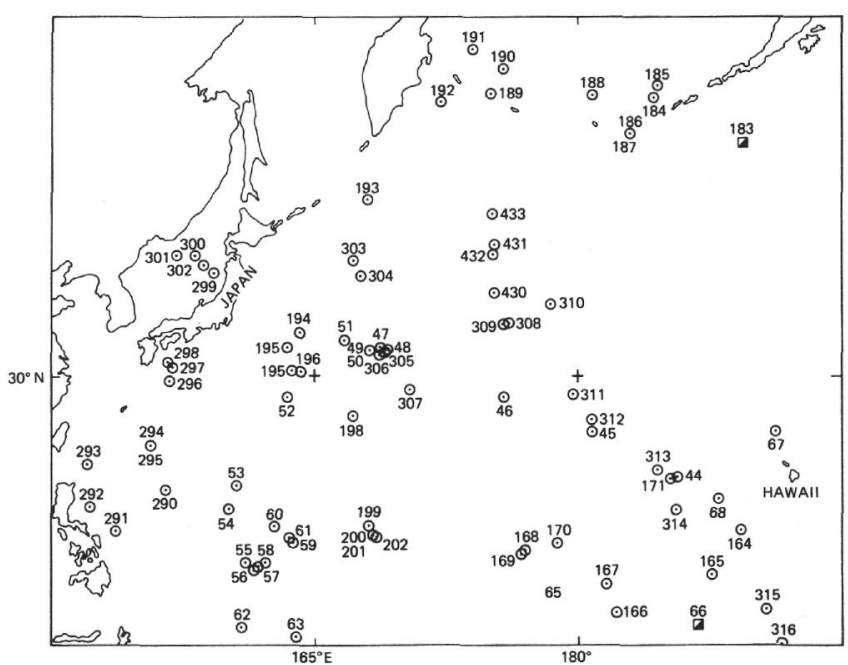

Figure 4. Distribution of sediments of Distephanus schauinslandii and coeval zone in the western North Pacific. (See Table 2 for key to symbols.)

study, the latitudinal orientation for their distribution is apparent.

\section{Silicoflagellate and Ebridian Occurrence at Each Site}

Although a total of 11 holes was drilled in four seamounts during the cruise, the recovery of soft sediments was disappointingly low (see Table 1) apparently because all the drilling was attempted on top of the seamounts.

\section{Site 430}

Among the three holes drilled into what appeared to be a lagoonal sediment pond of Ōjin Seamount, only surface samples from Hole 430B (Sample 1-1, 0-3 cm) contained well-preserved and abundant silicoflagellates of a modern assemblage of the middle latitude region. 


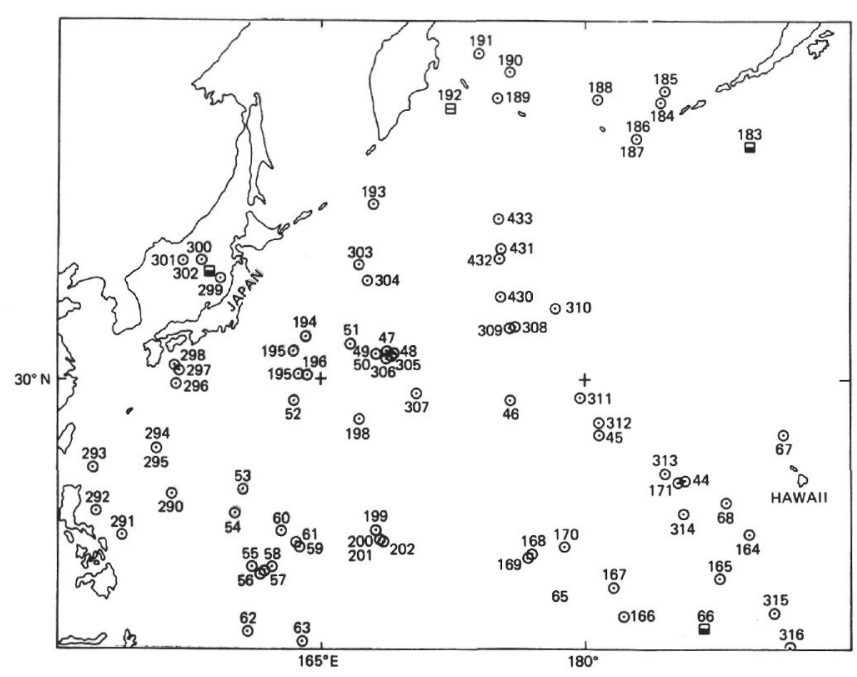

Figure 5. Distribution of sediments of Mesocena circulus apiculata and coeval zone in the western North Pacific. (See Table 2 for key to symbols.)

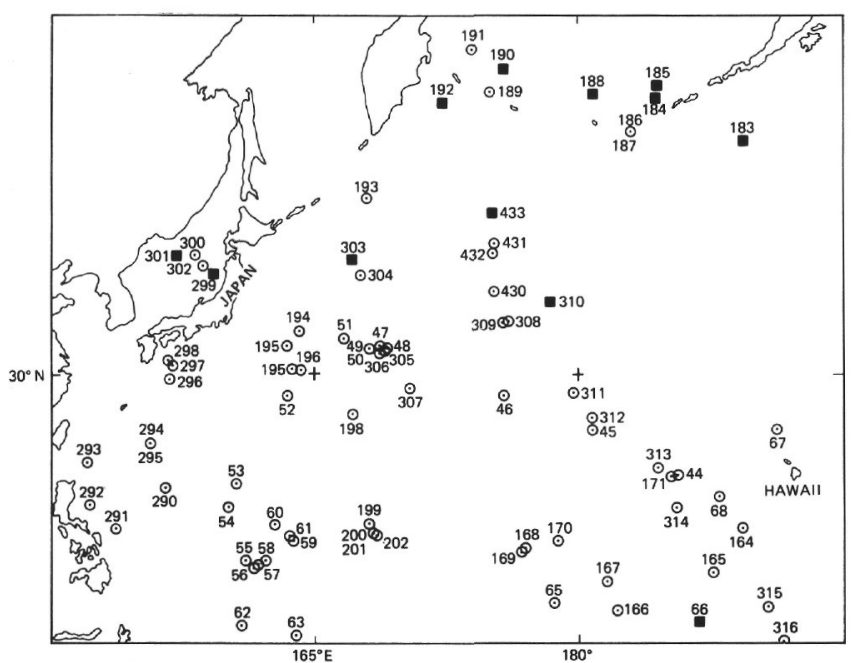

Figure 6. Distribution of sediments of Distephanus quinquangellus and coeval zone in the western North Pacific. (See Table 2 for key to symbols.)

\section{Site 431}

Although two holes were drilled into a faulted terrace on the east side of the newly proposed Yōmei Seamount (Dalrymple, personal communication), this group of siliceous microplanktonic remains was completely absent from the cored deep-sea sediments.

\section{Site 432}

Among the sediments cored from two holes of the presumed perched terrace deposits on the top of Nintoku Seamount, well-preserved but rare Dictyocha messanensis specimens were recovered.

\section{Site 433}

It was only at this re-entry site that well-preserved and generally common to abundant silicoflagellates and

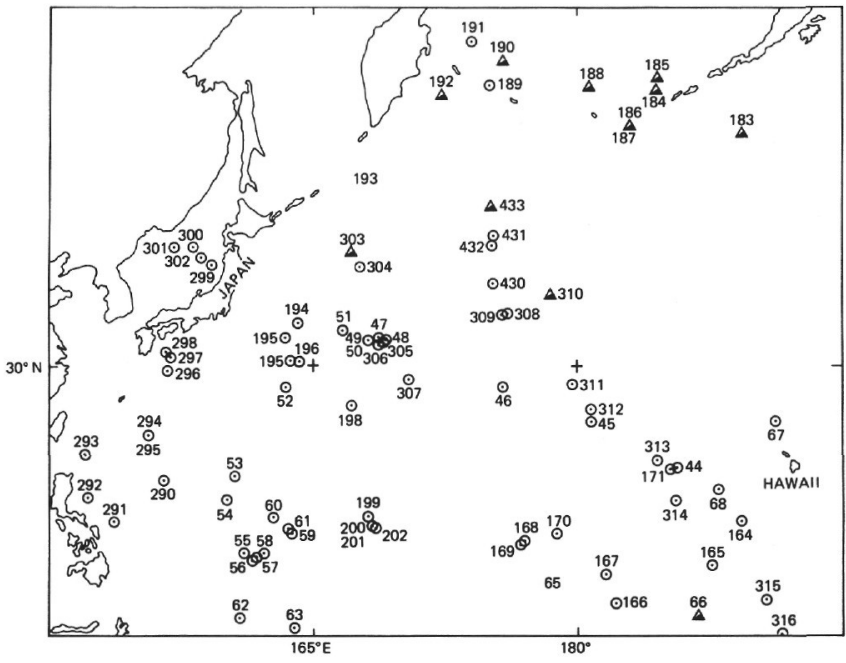

Figure 7. Distribution of sediments of Distephanus jimlingii and coeval zone in the western North Pacific. (See Table 2 for key to symbols.)

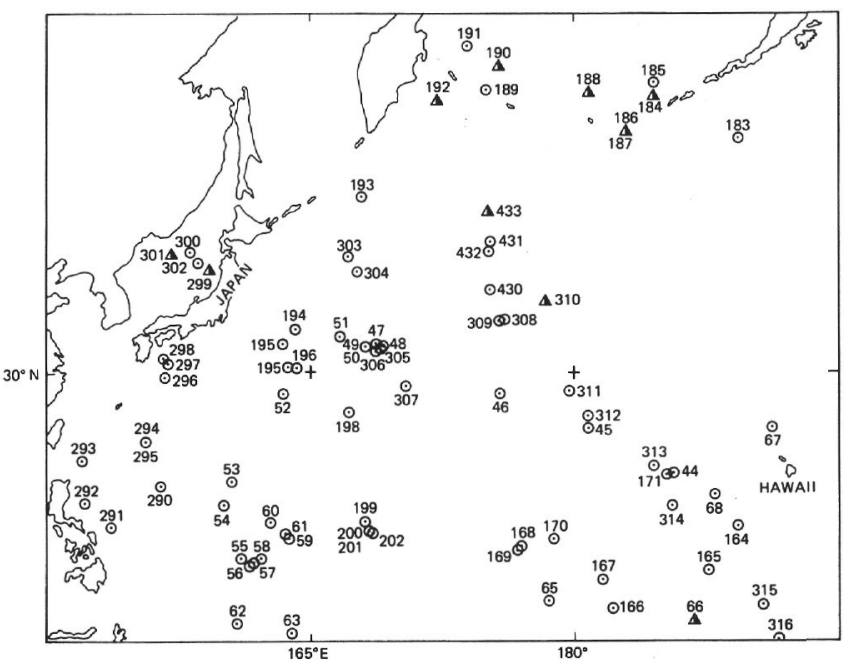

Figure 8. Distribution of sediments of Ebriopsis antiqua antiqua and coeval zone in the western North Pacific. (See Table 2 for key to symbols.).

ebridians were finally encountered. The drill holes were located in a complexly deformed marginal structural basin associated with a fairly extensive lagoonal complex on the top of Suiko Seamount.

\section{Hole 433}

One sample, $1-1,75-77 \mathrm{~cm}(0.7 \mathrm{~m})$, was barren of this group of siliceous microfossils, but Sample 1-2, $10-13 \mathrm{~cm}(1.6 \mathrm{~m})$ belongs to the Distephanus octonarius Zone, and Sample 1-2, 113-115 cm (2.6 m) is recognized as belonging to the Ebriopsis antiqua antiqua Zone. Thus, the lower Pleistocene Dictyocha subarctios and upper Pliocene Ammodochium rectangulare zones were apparently not encountered. From Sample 1-3, 94-97 $\mathrm{cm}(3.9 \mathrm{~m})$ down to $1, \mathrm{CC}$, the bottom of this hole belongs to the lower Pliocene Distephanus jimlingii Zone (Table 4). 


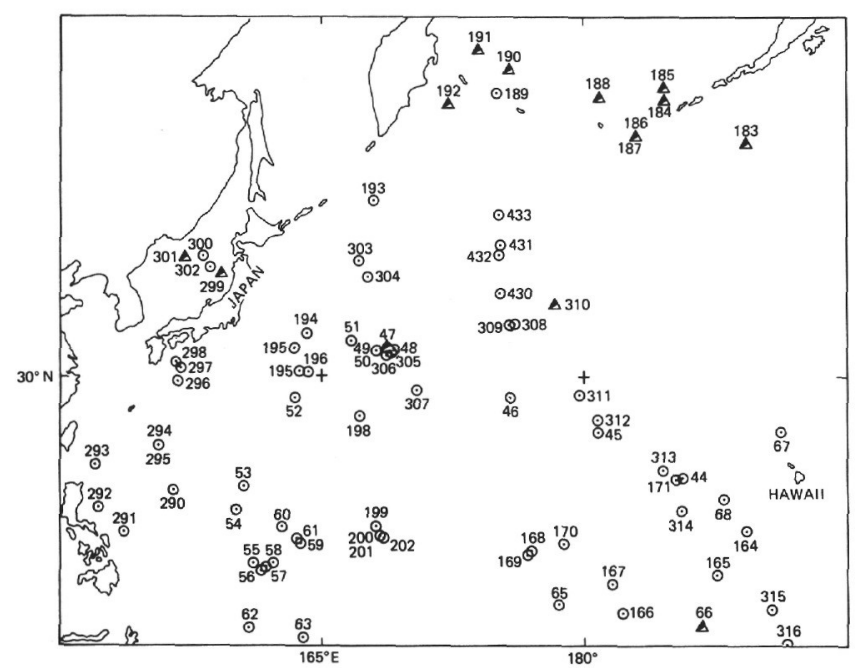

Figure 9. Distribution of sediments of Ammodochium rectangulare and coeval zone in the western North Pacific. (See Table 2 for key to symbols.)

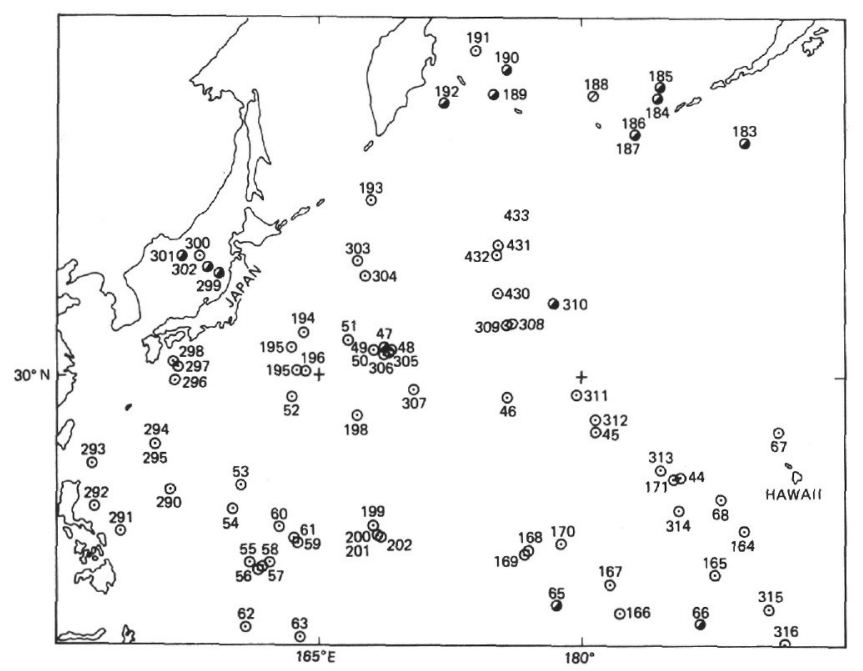

Figure 10. Distribution of sediments of Dictyocha subartios and coeval zone in the western North Pacific. (See Table 2 for key to symbols.)

\section{Hole 433A}

Although Samples 1-1, 4-13 cm (about $0.1 \mathrm{~m}$ ) and $1-1,23-25 \mathrm{~cm}(0.2 \mathrm{~m})$ failed to yield either silicoflagellates or ebridians, the sediments are considered to be upper Pleistocene, on the basis of co-occurring radiolarians (Ling, this volume) and diatoms (Koizumi, this volume). One sample, $1-1,70-73 \mathrm{~cm}(0.7 \mathrm{~m})$, is identified as belonging to the Ebriopsis antiqua antiqua Zone, and is characterized by the occurrence of nominated species. This would suggest an unconformity encompassing an interval from lower Pleistocene to at least upper Pliocene. The section from sediment Samples 1-1, 133-135 $\mathrm{cm}(1.3 \mathrm{~m})$ to $3, \mathrm{CC}(24 \mathrm{~m})$ is of the Distephanus jimlingii Zone.

The uppermost occurrence of Distephanus quinquangellus, in Sample 4-1, 13-15 cm (24 m) marks the top of

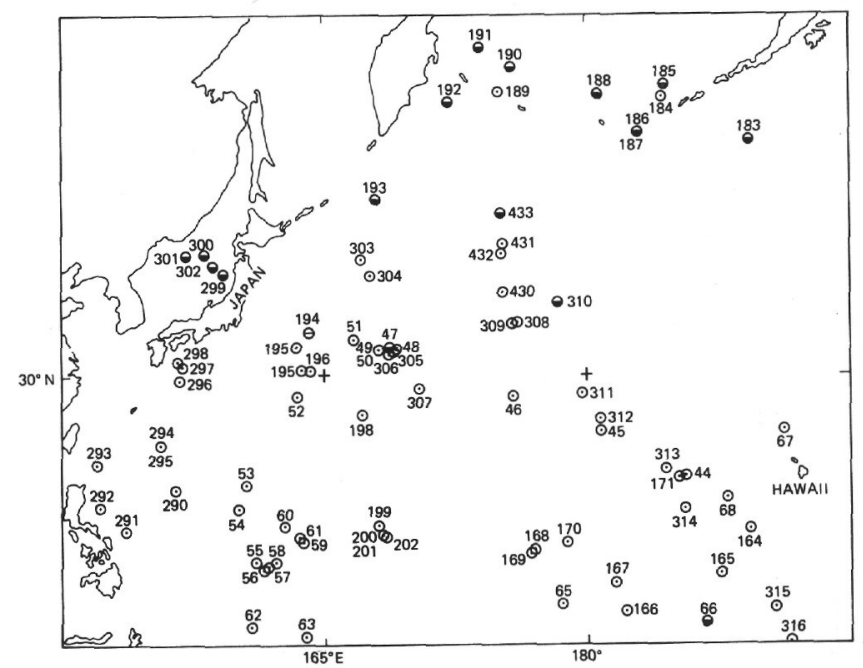

Figure 11. Distribution of sediments of Distephanus octonarius and coeval zone in the western North Pacific. (See Table 2 for key to symbols.)

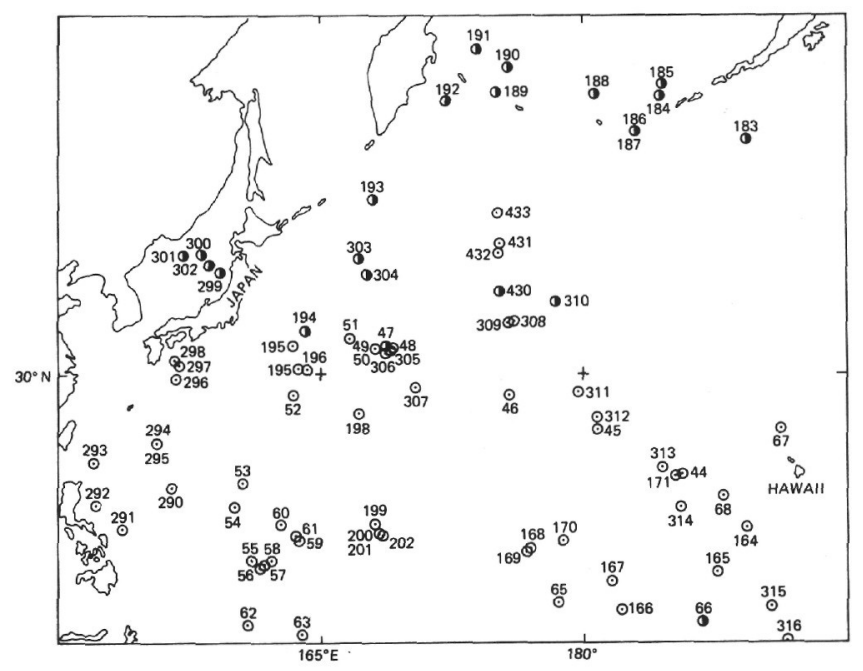

Figure 12. Distribution of sediments of Distephanus octangulatus and coeval zone in the western North Pacific. (See Table 2 for key to symbols.)

the Miocene as observed in high latitude areas of the North Pacific (Ling, 1973) and the Japan Sea (Ling, 1975).

Although rare, the presence of Corbisema triacantha below Sample 6-6, 140_142 cm (51.9 m), through Core 7 $(62 \mathrm{~m})$, probably suggests the middle Miocene Corbisema triacantha Zone (Table 5). Neither silicoflagellates nor ebridians were found in sediments below Core 8 $(62 \mathrm{~m})$.

\section{Hole $433 B$ and $433 C$}

Both silicoflagellates and ebridians were completely absent from drilled sediments of these two holes.

\section{TAXONOMIC REFERENCE LIST}

Silicoflagellates and ebridians from the sediment samples of the western North Pacific region have recent- 
TABLE 4

Silicoflagellate and Ebridian Species Distribution, Abundance, and Preservation, Hole 433

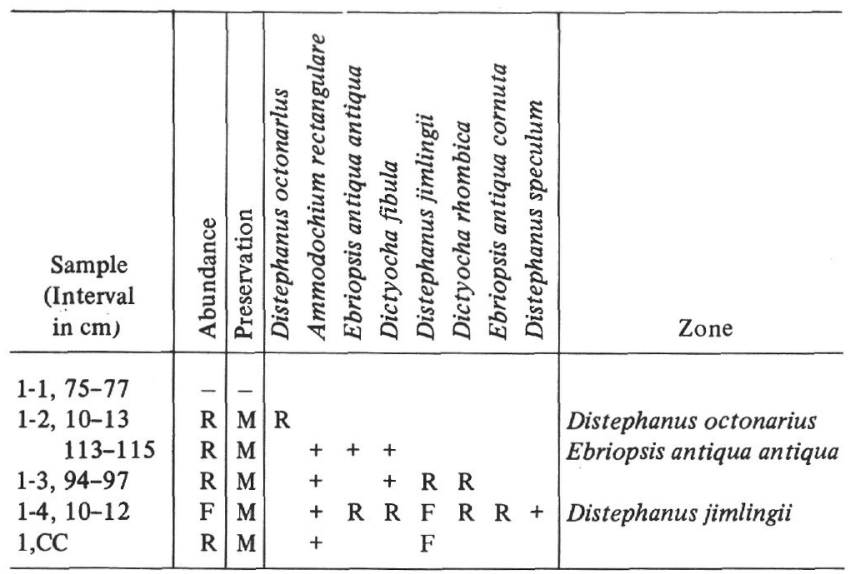

Note: $\mathrm{R}=$ rare $; \mathrm{F}=$ few $;+=$ present $\mathrm{M}=$ moderate.

ly been treated in detail (for the details, see, e.g., Bukry 1979, and Ling, 1977); consequently, the preferred names used throughout the investigation are listed in alphabetical order, followed by the original epithets of the taxa. Only limited additional comments are given to those taxa, whenever it seems appropriate.

\section{Silicoflagellates}

Corbisema bimucronata Deflandre, 1950, pp. 63/82, 64/82, figures 174-177 (Plate 1, figures 1-3).

Corbisema hastata minor (Schulz), Bukry, 1975, p. 854, pl. 1, fig. 10 = Dictyocha triacantha var. apiculata fa. minor Schulz, 1928 (partim) p. 249, figure 29b (Plate 1, figures 4-6).

Corbisema triacantha (Ehrenberg), Hanna, 1931, p. 198, pl. D, figure 1.

Dictyocha aspera aspera Bukry, 1976, p. $723=$ Dictyocha fibula var. aspera Lemmermann, 1901, p. 260, pl. 10, figures 27, 28 (Plate 2, figure 1).

Dictyocha aspera clinata Bukry, 1975, p. 695, pl. 1, figures 1-5 (Plate 2, figure 4).

Dictyocha ausonia Deflandre, 1950, pp. 67/82, figures 194, 199, 200 (?), 201, 202 (?) (only) (Plate 2, figure 3).

Dictyocha brevispina (Lemmermann), Bukry, 1976, p. $723=$ Dictyocha fibula var. brevispina Lemmermann, 1901, p. 260 (Plate 1, figure 7).

Dictyocha fibula Ehrenberg, 1839, p. 129 (Plate 2, figure 5).

Dictyocha mandrai Ling, 1977, pp. 209, 210, pl. 1, figures 13, $14=$ Dictyocha fibula var. aculeata Lemmermann, 1901, p. 261, pl. 11, figures 1, 2 (Plate 1, figure 10).

Dictyocha rhombica (Schulz), Bukry, 1975, pl. 4, figures 5, $6=$ Dictyocha fibula fa. rhombica Schulz, 1928, p. 253, figure 37. Remarks: As discussed previously (Ling, 1970), the difference between this taxon and $D$. ausonia is its larger dimension, approximately 1.5 times that of the latter. Examination of the western North Pacific sediments confirms further that they show similar biostratigraphic and paleogeographic occurrences (Plate 1, figure 2).

Dictyocha sp. cf. D. calida Poelchau, 1976, p. 169, 170, pl. 1, figures c, d; pl. 3, figures a-f. Remarks: The specimens recognized here are similar to $D$. calida except that their larger dimension is at least 1.5 times that of the latter. In the western North Pacific, e.g., Site 310 , the geological range of the species extends to the upper Pliocene (Plate 1, figures 8, 9).

Dictyocha subarctios Ling, 1970, pp. 95, 96, pl. 18, figures 16-18, pl. 19, figures 1-4 (Plate 1, figure 2).

Distephanus crux (Ehrenberg), Haeckel, 1887, p. 1563 = Dictyocha crux Ehrenberg, 1840, pp. 207, 208 (Plate 2, figure 8).
Distephanus jimlingii (Bukry), Bukry, 1979, p. 561, pl. e, figures 7-12 $=$ Distephanus boliviensis jimlingii Bukry, 1975, p. 688, pl. 1, figures 6, 7 (Plate 2, figures 6, 7).

Distephanus octangulatus Wailes, 1932, p. 216, figure 3 (Plate 2, figure 9).

Distephanus octonarius Deflandre, 1932, p. 503, figure 7.

Distephanus quinquangellus Bukry and Foster, 1973, p. $828=$ Distephanus speculum var. pentagonus Lemmermann, 1901, p. 264, pl. 11, figure 19 (Plate 2, figure 10).

Distephanus sp. cf. D. quinquangellus Bukry and Foster, 1973. Remarks: During the western North Pacific analysis, specimens of similar skeletal configuration but with much larger dimension than the above taxon are frequently observed in the same samples (Plate 1 , figures 12,13$)$.

Mesocena circulus (Ehrenberg), Ehrenberg, 1884, pg. 65 = Dictyocha (Mesocena) circulus Ehrenberg, 1840, p. 208 (Plate 2, figure 12) (Plate 1, figure 14).

Mesocena diodon Ehrenberg, 1844, pp. 71, 84 (Plate 2, figure 13).

Mesocena elliptica (Ehrenberg) Ehrenberg, 1844, p. 71, $84=$ Dictyocha (Mesocena) elliptica Ehrenberg, 1840, p. 208 (Plate 2, figure 14).

Mesocena quadrangula Ehrenberg ex Haeckel, 1887, p. 1556 (Plate 1, figure 15).

Naviculopsis iberica Deflandre, 1950, pp. 74/82-76/82, figures 231-234 (Plate 1, figure 16).

\section{Ebridians}

Ammodochium rectangulare (Schulz) Deflandre, 1932, pp. 303-305, figures $1-13=$ Ebria antiqua var. rectangularis Schulz, 1928, p. 274, figures 72 a-d (Plate 2, figure 15).

Ebriopsis antiqua antiqua (Schulz), Ling, 1971 (partim), p. 693, pl. 1, figures 21-23 (only); = Ebria antiqua Schulz, 1928 (part), pp. 273, 274, figure 69b (only) (Plate 2, figure 16).

Ebriopsis antiqua cornuta Ling, 1977, pp. 215, 216, pl. 3, figures 19-22 = Ebria antiqua Schulz, 1928 (part), pp. 273, 274, figures 69 e, f (only) (Plate 2, figure 17).

Ebriopsis crenulata Hovasse, 1932, p. 281, figures 4, I, II (Plate 1, figures 17-19).

Hermedium adriaticum Zacharias, 1906, fide Loeblich et al., 1968, p. 168, figure 20; pl. 40, figures 9 a-c, 10 .

\section{ACKNOWLEDGMENTS}

I was pleased to have the opportunity to participate in the three cruises of the North Pacific Ocean, and sincere appreciation is extended to the Deep Sea Drilling Project for inviting me to be a shipboard scientist. The operation of the project was funded by the National Science Foundation and a part of the research was supported through an NSF grant (OCE7520434).

Special thanks are due to my wife Su Yu Lee and children, Dorothy and Richard, for their utmost understanding and cheerful endurance of three long summer sessions.

\section{REFERENCES}

Bukry, D., 1979. Coccolith and silicoflagellate and stratigraphy, northern Mid-Atlantic Ridge and Reykjanes Ridge, Deep Sea Drilling Project Leg 49. In Luyendyk, B. P., Cann, J. R., et al., Initial Reports of the Deep Sea Drilling Project, v. 49: Washington (U.S. Government Printing Office), p. 751-755.

Ling, H. Y., 1973. Silicoflagellates and ebridians from Leg 19. In Creager, J. S., Scholl, D. W., et al., Initial Reports of the Deep Sea Drilling Project, v. 19: Washington (U.S. Government Printing Office), p. 751-755.

1975. Silicoflagellates and ebridians from Leg 31. In Karig, D. E., Ingle, J. C., Jr. et al., Initial Reports of the Deep Sea Drilling Project, v. 31: Washington (U.S. Government Printing Office), p. 763-777. 
1977. Late Cenozoic silicoflagellates and ebridians from the eastern North Pacific region. First Internat. Congr. Pacific Neogene Stratigraphy, Tokyo, 1976, Proc., p. 205-233.

Ling, H. Y., and McPherson, L. M., 1976. Silicoflagellates and ebridians from the Naduara area, Noto Peninsula, Japan. In Takayanagi, Y., and Saito, T. (Eds.), Progress in Micropaleontology: Amer. Mus. Natural History, Spec. Publ., p. 160-168.
Martini, E., 1974. Silicoflagellate zones in the Eocene and early Oligocene, Senckenberg. Leth., v. 54, nos. 5/6, p. 527-532.

Martini, E., and Müller, C., 1976. Eocene to Pleistocene silicoflagellates from the Norwegian-Greenland Sea (DSDP Leg 38). In Talwani, M., Udintsev, G., et al., Initial Reports of the Deep Sea Drilling Project, v. 38, Washington (U.S. Government Printing Office), p. 857-895.

TABLE 5

Silicoflagellate and Ebridian Species Distribution, Abundance, and Preservation, Hole 433A

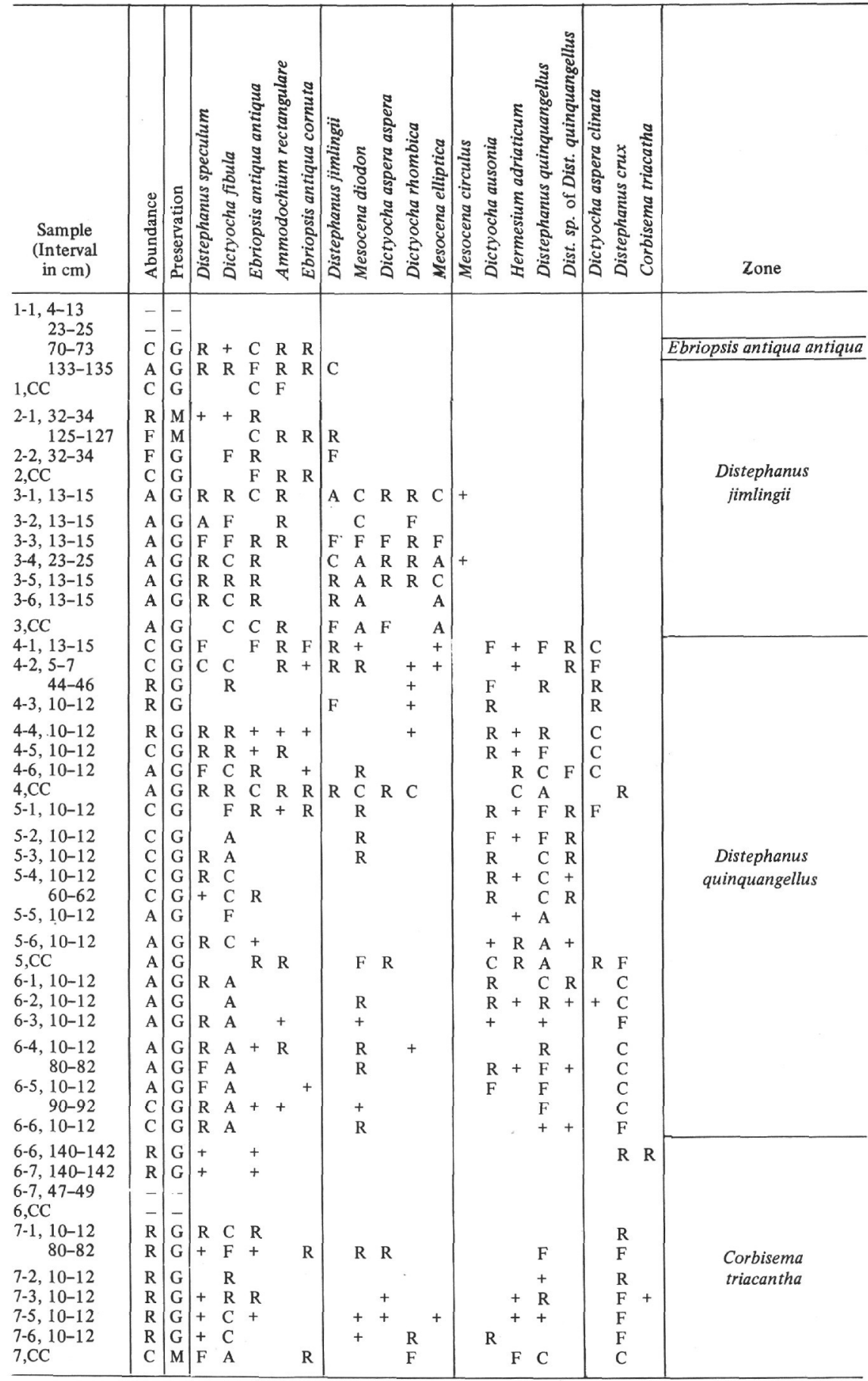

Note: $\mathrm{A}=$ abundant $; \mathrm{C}=\operatorname{common} ; \mathrm{F}=$ few $; \mathrm{R}=\operatorname{rare} ;+=\operatorname{present} ; \mathrm{G}=$ good $; \mathrm{M}=$ moderate 
PLATE 1

(Magnification $500 \times$ unless otherwise indicated.)

Figures 1-3 Corbisema bimucronata

1, 2. 165A-8-4, 119-120 cm, L-2 (H36/0)

3. $165 \mathrm{~A}-8-4,119-120 \mathrm{~cm}, \mathrm{~L}-2$ (S9/4)

Figures 4-6 Corbisema hastata minor

4. 165A-8-4, 119-120 cm, L-2 (E12/1)

5, 6. $165 \mathrm{~A}-8-4,119-120 \mathrm{~cm}, \mathrm{~L}-2(\mathrm{U} 33 / 0)$

Figure 7 Dictyocha brevispina 65-13, 120-121 cm, L-2 (N18/0)

Figures 8, 9 Dictyocha sp. ct. D. calida

8, 9. 310-3-2, 118-119 cm, L-2 (Y15/0)

Figure 10 Dictyocha mandrai 303-1-1, 100-101 cm, L-2 (L38/2)

Figure 11 Dictyocha subarctios 310-3-2, 118-119 cm, L-2 $(\mathrm{F} 15 / 2)$

Figures 12, 13 Distephanus sp. cf. D. quinquangellus. 12, 13. 303-4-6, 120-121 cm, L-2 (O10/4)

Figure 14 Mesocena circulus 303-2-6, 100-101 cm, L-2 (U10/1)

Figure 15 Mesocena quadrangula 303-3-2, $52-53 \mathrm{~cm}, \mathrm{~L}-2$ $(\mathrm{H} 12 / 3)$

Figure $16 \quad$ Naviculopsis iberica 303-4-6, 120-121 cm, L-2 $(\mathrm{T} 8 / 1)$

Figures 17-19 Ebriopsis crenulata

17, 18. 165A-8-4, 119-120 cm, L-2 (H36/0), $\times 800$

19. $166-12-1,30-31 \mathrm{~cm}, \mathrm{~L}-2(\mathrm{R} 29 / 3), \times 800$ 
PLATE 1
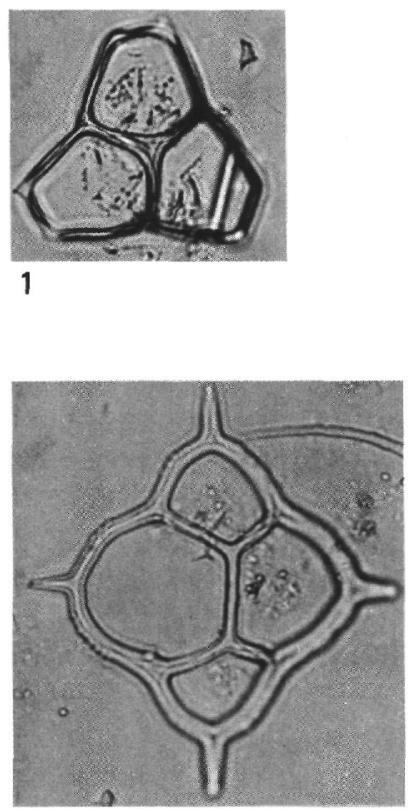

8

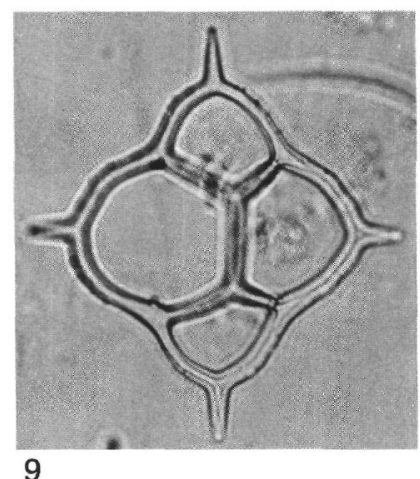

9
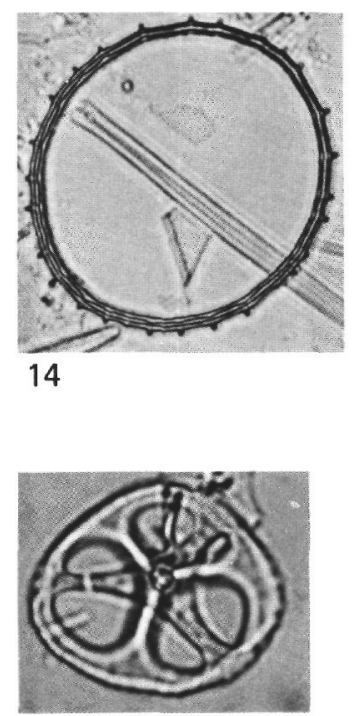

17
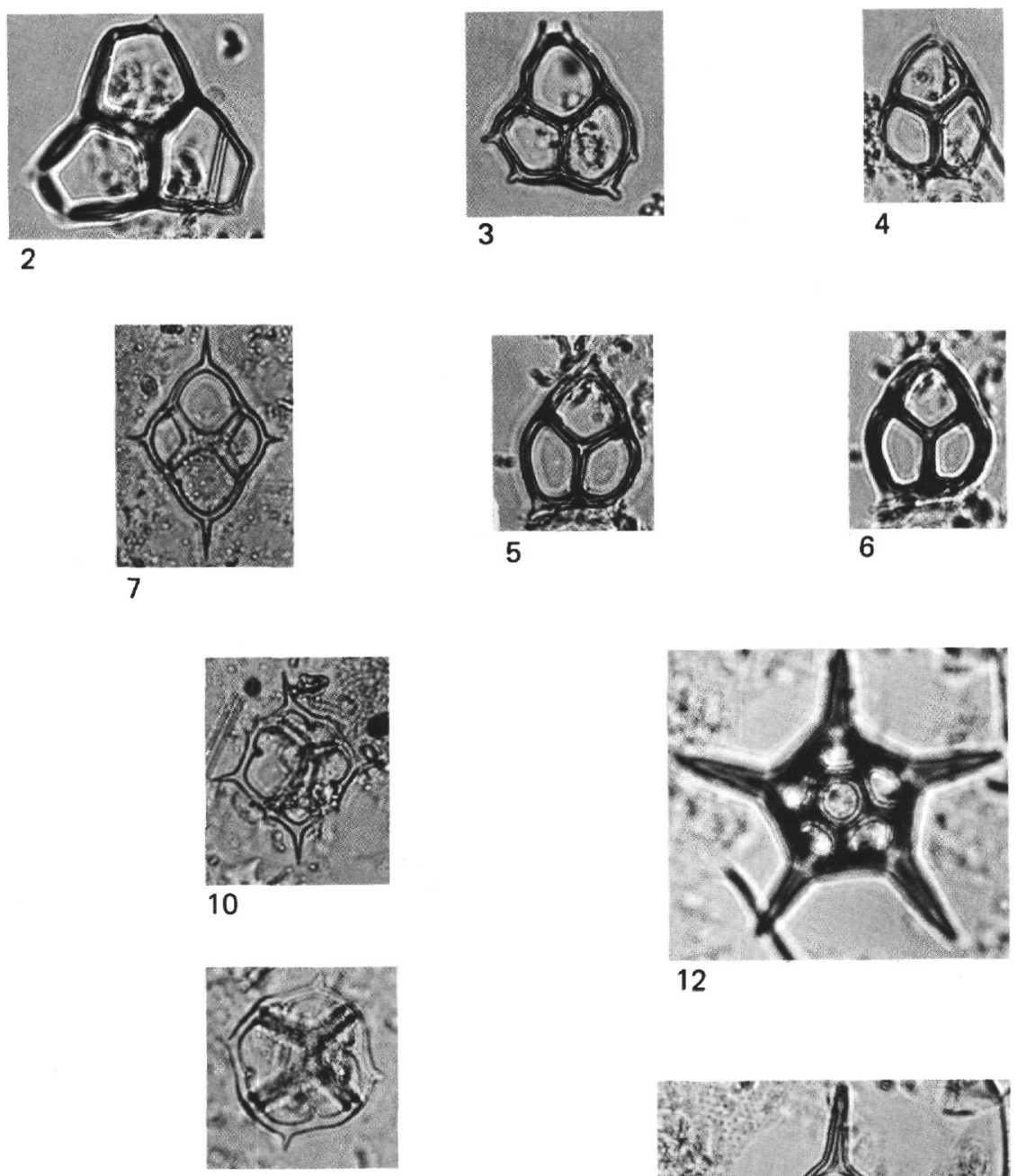

11

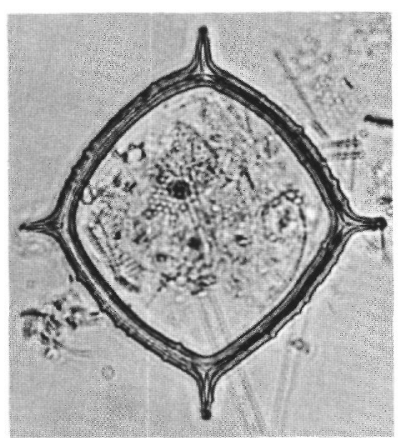

15

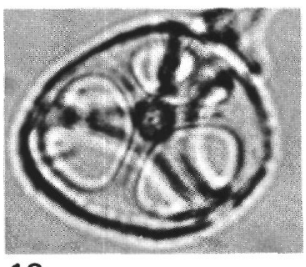

18
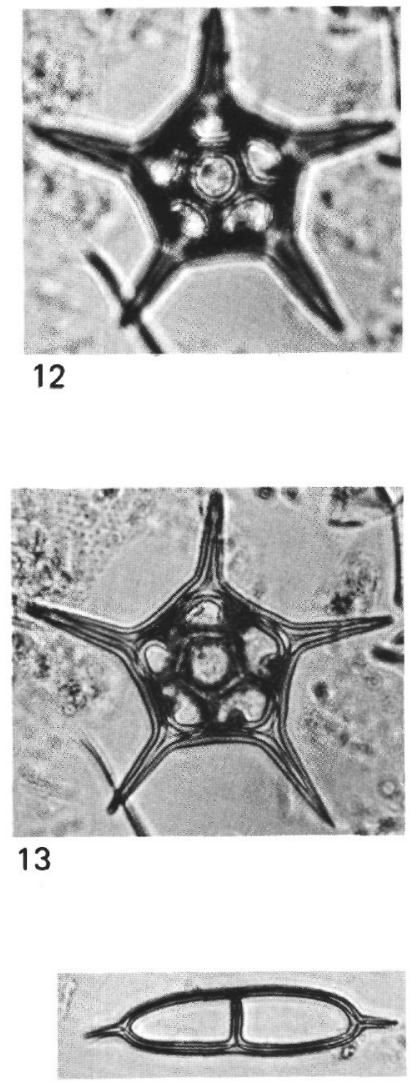

16

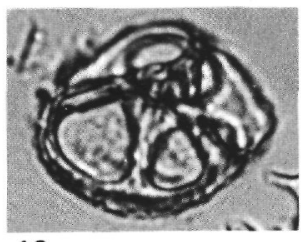


PLATE 2

(Magnification $500 \times$ unless otherwise indicated.)

Figure 1 Dictyocha aspera aspera 433A-31, 13-15 cm, L-2 (U39/3)

Figure 2 Dictyocha rhombica

Figure 3 Dictyocha ausonia 433A-4-5, 10-12 cm, L-2 (Q7/0)

Figure 4 Dictyocha aspera clinata 433A-4-2, 5-7 cm, L-2 (F9/3)

Figure 5 Dictyocha fibula 433A-6-5, 90-92 cm, L-2 (U5/0)

Figures 6, 7 Distephanus jimlingii

6. $433 \mathrm{~A}, 1 \mathrm{CC}, \mathrm{L}-2(\mathrm{X} 33 / 0)$

7. 433A, 3-3, 13-15, L-2 (Y9/2)

Figure 8 Distephanus crux 433A-7-1, 80-82 cm, L-2 (S7/0)

Figure 9 Distephanus octangulatus 303-1-1, 100-101 cm, $\mathrm{L}-2(\mathrm{R} 21 / 0)$

Figure 10 Distephanus quinquangellus 433A-4, CC, L-2 (T3/0)

Figure 11 Distephanus speculum 433A-3-2, 13-15 cm, L-2 (Q20/4)

Figure 12 Mesocena circulus 433A-3-1, L-2 (M31/4)

Figure 13 Mesocena diodon 433A-3-5, 13-15 cm, L-2 (U22/3)

Figure 14 Mesocena elliptica 433A-3-4, 23-25 cm, L-2 (K16/0)

Figure 15 Ammodochium rectangulare 433A-4-1, 13-15 cm, L-2 $(\mathrm{O} 40 / 0) \times 800$

Figure 16 Ebriopsis antiqua antiqua 433A-3-1, 13-15 cm, $\mathrm{R}-1(\mathrm{~K} 25 / 4) \times 800$

Figure 17 Ebriopsis antiqua cornuta 433-1-4, 10-12 cm, L-2 $(\mathrm{U} 5 / 0) \times 800$ 
PLATE 2
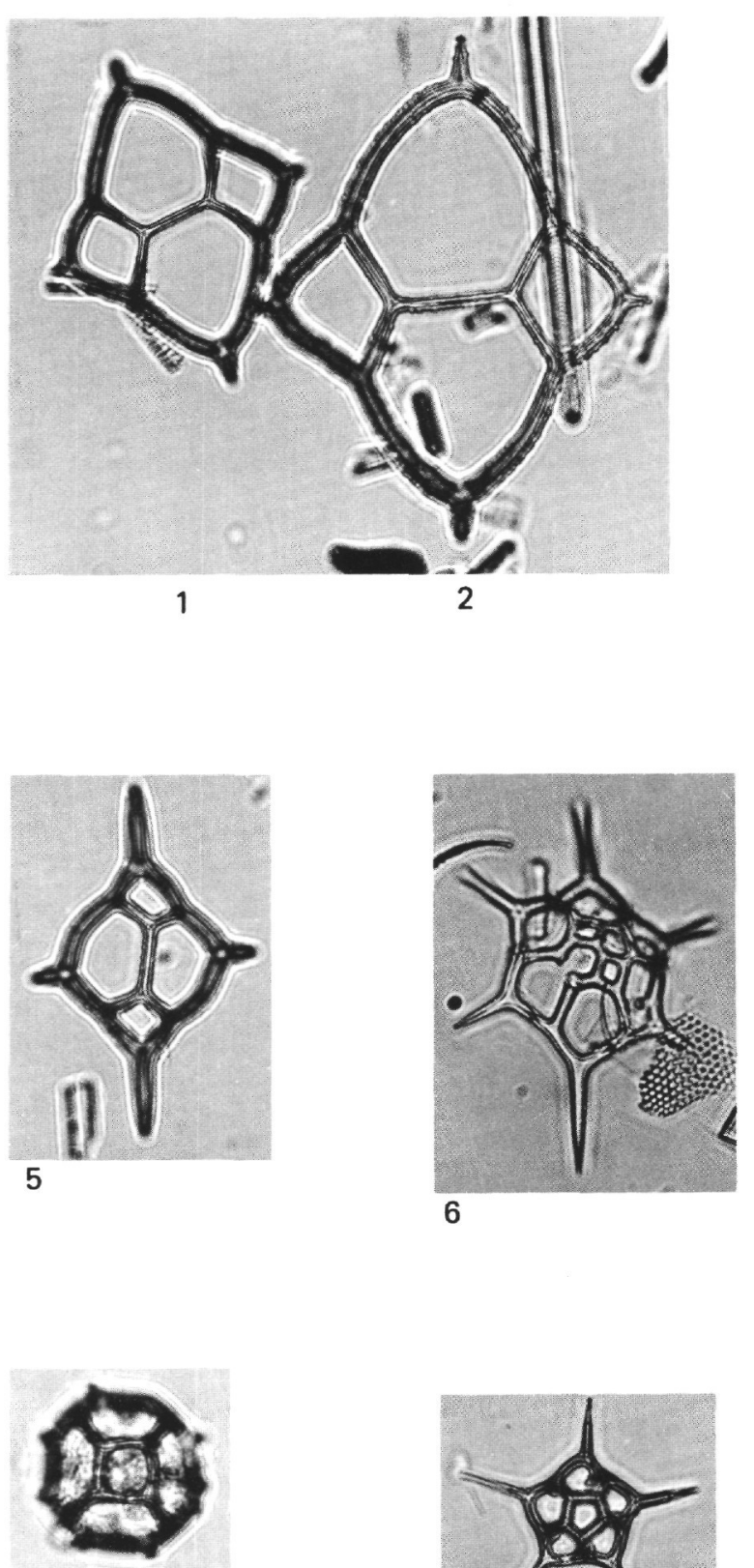

9
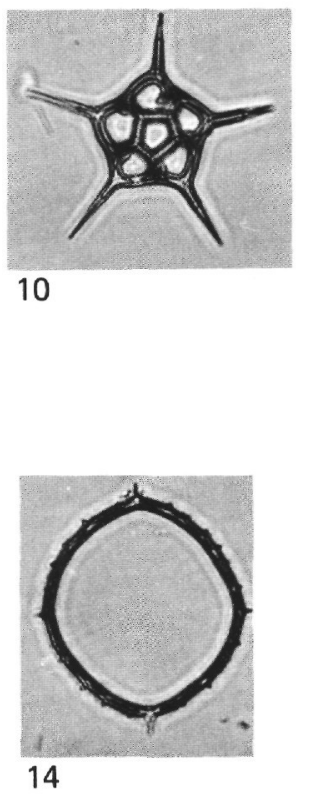
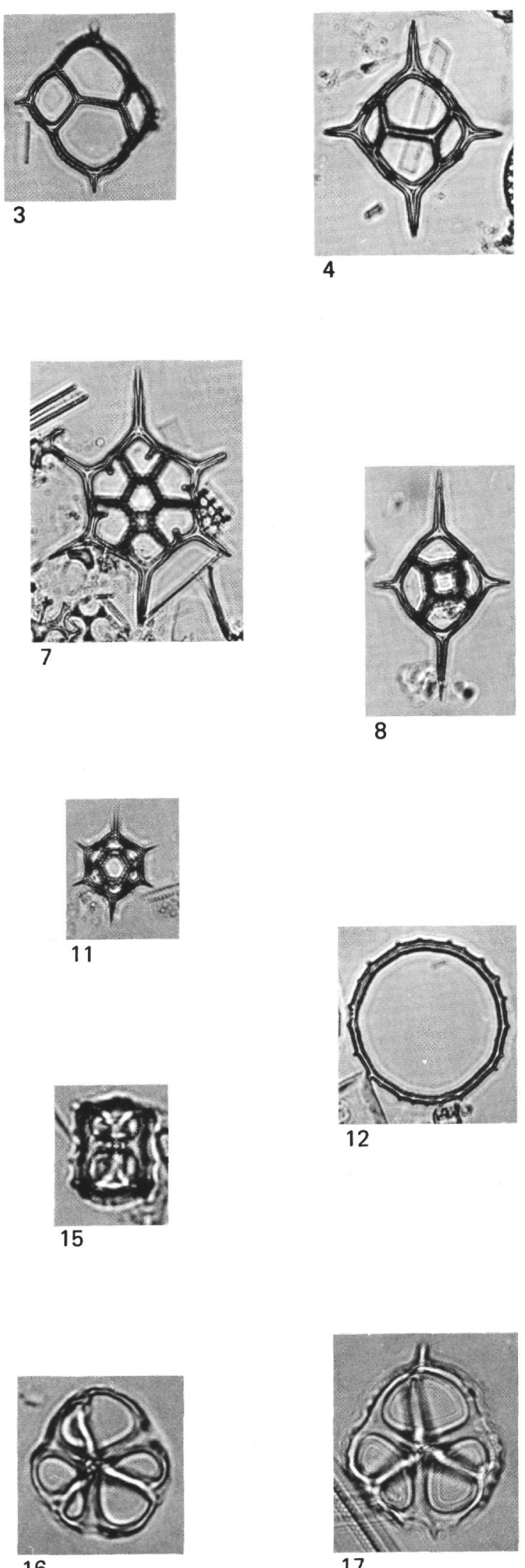